\title{
NEW EXPLORATORYTECHNOLOGY AND ITS ADAPTATION TO OIL AND GAS FACILITIES WITHIN IMPACT STRUCTURES IN UKRAINE
}

\section{НОВА ПОШУКОВА ТЕХНОЛОГІЯ ТА ІЇ̈ АААПТАЦІЯ НА НАФТОГАЗОНОСНИХ ОБ'ЄКТАХ ІМПАКТНИХ СТРУКТУР УКРАїнИ}

\author{
Igor D. Bagriy \\ I.A. Багрій
}

Institute of Geological Sciences, NAS of Ukraine, 55-b O. Honchara Str., Kyiv, Ukraine, 01601 (bagrid@ukr.net)

The potential for oil and gas exploration efficiency enhancement in consequence of the implementation of scientifically grounded theoretical concepts and new technologies of studying unconventional oil and gas facilities - impact structures is considered. A summary review is enounced regarding scientific investigations and manufacturing activities estimation of hydrocarbon prospects impact structures crystalline basement within the territory of Ukraine as well as in foreign countries. Nuanced analysis of data available brings us to the conclusion that direct-search soil vapor anomalies over oil and gas deposit areas are of diffusive nature. This has made it possible to turn to good advantage in estimating of unconventional facilities including impact structures. For illustrative purposes, cartographic results of Obolon' impact structure investigation are represented. Also, analysis of Siljan impact structure satellite survey was carried out. As a result of which, several methodological principle for further studying oil and gas potential of Siljan impact structure were proposed. Industrial introduction of authors' methodical technology may cause not only discovery of new commercial oil and gas deposit, but also carrying out task-oriented prospecting for presumable petroleumbearing impact structures within the boundaries of Ukrainian shield, Dnieper-Donets Basin and other areas.

Keywords: impact structures, the crystalline basement, direct exploratory geochemical methods, oil and gas facilities.

Розгяянуто можливість піАвищення ефективності геологорозвідувальних робіт на нафту і газ в результаті впровадження науково обгрунтованих теоретичних уявлень і нових технологій вивчення нетрадиційних нафтогазоносних об'єктів - імпактних структур. Наведено короткий огляА наукових Аосліджень і виробничих робіт з оцінки перспектив нафтогазоносності імпактних структур кристалічного фундаменту як за кордоном, так і на території України. На основі багаторазового аналізу наявних даних зроблено висновок про Аифузійну природу прямопошукових газогеохімічних аномалій наА нафтовими і газовими родовищами. Це Аозволило ефективно використовувати при оцінці нетрадиційних об'єктів, у тому числі імпактних структур, комплекс геолого-структурно-термо-атмогеохімічних АосліАжень (СТАГА). Як приклаА наведено картографічні результати вивчення цим методом Оболонської імпактної структури. Виконано також аналіз аерокосмічних зйомок по Сильянській імпактній структурі і запропоновано деякі рекомендації щодо подальшого вивчення ії нафтогазоносності. Впровадження методичних піАготовок і технологій автора може привести не тільки до відкриття нових промислових покладів нафти і газу, але і до проведення цілеспрямованих пошуків потенційно нафтогазоносних імпактних структур на Українському щиті, в Аніпровсько-Аонецькій западині та інших регіонах.

Ключові слова: імпактні структури, кристалічний фундамент, прямопошукові газогеохімічні методи, нафтогазові об'єкти.

\section{INTRODUCTION}

Recently, in the known areas of the oil and gas industry, the state of the raw material base is characterized by steady production decline due to a long-term exhaustion involved in the commercial development of oil and gas fields, and putting into operation almost $100 \%$ of new deposits can be grounded only by sedimentary-migration theory of hydrocarbons origin.

In Ukraine, it is, unfortunately, impossible to solve this problem by concentrating the forces and resources on the development of traditional oil and gas facilities, because of their complex structure, small sizes and considerable depths.

Taking this into account, the solution for such a critical situation can be found through new tech- nological methods, commercially available and economically feasible approaches, modified methods of industrial development of unconventional exploration objects, in particular impact structures.

The firsts attempts on studying the oil and gas objects in crystalline rocks and impact structures in Ukraine were initiated by V.B. Porfiriev, V.A. Krayushkin, V.P. Klochko and A.E. Lukin, starting from the 60 s of the twentieth century and were aimed at the investigation of the nature and peculiarities of the oil and gas capacity of impact structures and possible conditions for oil and gas accumulation in the above crateral and under crateral fractured zones of the impact structures.

According to the American Academy of Sciences, only since 1980 the US government has provided

(C) Igor D. Bagriy, 2016 
funding in the amount of 10 million dollars for scientific studies, in particular, for the development of prospects in crystalline rocks, in addition 4 million dollars were given for drilling to a depth of $5 \mathrm{~km}$, that led to significant discoveries of commercial oil and gas impact structures (Gozhyk et al., 2010).

Analyzing the results of the discovery of commercial deposits of oil and gas in the Williston Basin impact structures, where a large amount of drilling have been carried out, we conclude that the success rate is approaching to 1 . All the commissioned for oil and gas impact structures proved to be a commercial deposits (Viewfield, Newporte and Red Wing Creek structures).

Statistics of successful search for oil and gas in the areas of impact structures development indicates not $100 \%$ results at all drilled wells, but the most important conclusion - all impact structures turned to be oil and gas productive. Consequently, the creation of a new direct search technology will help to increase the success rate significantly.

According to our preliminary analysis of the results of research of oil and gas potential impact structures in Ukraine, it is possible to assert that if each structure achieves a success factor of 0.25 or even 0.1 , then potential oil and gas resources in Ukraine will exceed the initial total exploration reserves of sedimentary strata in Ukraine.

Therefore, today more than ever there is an actual issue of increasing the efficiency. It concerns exploration for oil and gas because the present deplorable state of the efficacy of traditional prospecting, especially in non-traditional hydrocarbons, is expressed in a disastrously low efficiency of exploration drilling.

The significant rise in price of the works with no scientific theoretical foundation in practice for the preparation of oil and gas reserves, in addition the absence of revolutionary technical and technological solutions in this sphere led to the curtailment and stagnation of exploration of oil and gas in most regions of Ukraine, including new areas with unconventional hydrocarbons.

Scientific and methodical development of technology are merely tools in the geologist's hands and this prospector's approach led a large number of scientists and industrialists to the conclusion that "direct" theoretical and technical methods of oil and gas searches do not exist currently. Nowadays low confirmability coefficient of the results of prospecting work indicates an insufficient development of effective methodological and technical solution of the problem and the need for an approach to forecast oil and gas potential and mineral resources on the new genetic basis. Currently, seismic as the primary method of facilities preparation for the exploration drilling, even in three-dimensional design and the highest possible resolution, does not enable to detect oil deposits. It only maps out structures with a greater degree of reliability and detail. All the structures under certain favorable conditions may contain deposits of hydrocarbons, and at the same time they may not contain it. Only the "bit" can remove this uncertainty. The only question is, at what costs (Timurziyev, 1989).

The success rate of the search was in the range of 10-30\% in the past "low-tech" and in the current "high-tech" period in the United States and is kept within these limits, and will be kept till the oil companies offer new valid search technologies. The sense of increase the efficiency of these studies in offered by us direct search technology consists in justification complex of reflected signals and universal causal relationships which is based on the only genetic model reflection complex that includes spatial and stratigraphic localization of oil and gas deposits in the depths of the earth's crust. The knowledge of these links including the physicchemical, geological and structural conditions, thermodynamic processes of formation of deposits and oil and gas potential of reflected signals makes it possible to perform predictive mapping on the surface. The criteria for oil and gas potential, that is based on the laws of localization (volume concentration) identified reserves of hydrocarbon , is caused a set of science-based complex of relevant characteristics of the indirect reflected and direct search of signals.

The direct indicators differ from indirect not by their degree of reliability, but by the nature of connection with the reservoir (deposit). Direct indicators mean a search of fields, that are conducted on the basis of fixed ones on the earth's surface (also in the surface sediments, soils and aquifers that are not deeply laid) of only geochemical anomalies concerning hydrocarbons that is caused by accumulation but not by a trap.

Cases of full compliance with the practice of geological exploration of oil and gas are rare and observed for some that are not deeply laid and can be found only in specific geological conditions.

Low informativeness of hydrocarbon geochemical methods of direct search due to the lack of positive forecasts was explained by technical imperfec- 
tions of this or that technique, samplers and low sensitivity of gas analyzers. Evidently, it was connected with other deeper causes and primarily with insufficient study and reasonable interpretation of regularities that form oil and gas deposits and their reflection on the surface of halos of scattered HC as the sole indicator of direct search.

Till now during a theoretical justification of the diffusion mechanism of the formation of halos that are scattered over hydrocarbon deposits are not considered such fundamental factors as the ratio of the lateral extent and vertical migration of hydrocarbons in the formation of deposits and their echoes on the surface.

In addition, during the study and mapping fault zones of varying permeability, researchers faced the questions of their role in the process of migration and accumulation of hydrocarbons, there also considered the problems of multi-vector disparate methodological approaches presence and the absence of unified substantiated technology.

All this is the main cause of low efficiency of hydrocarbon geochemical direct exploratory methods, as well as various indirect indicators that are used of oil and gas fields forecasted areas. The last concerns not only the geochemical, but also geological-structural, hydrological and hydrogeological, thermodynamic conditions, as well as the issue of migration, filtration lithostratigraphy and hydrogeochemistry.

\section{THEORETICAL BACKGROUND}

All mentioned above indicates the unity of the complex processes in formation of hydrocarbon deposits and its diffusive and geothermal conditions. The established regularities are based on the analysis of multiple diffusive nature of direct exploratory hydrocarbon geochemical anomalies over oil and gas fields, according to the technology developed and applied by us (geological-structural-thermal-atmogeochemical research - STAGR) (Bagriy, Gozhyk, 2009; Bagriy, 2010), that can significantly refine and clarify the prognostic and perspective contours of the required productive facilities on the basis of a single processing mathematical and statistical methods of processing circuit testing, structural and geological information.

According to the offered STAGR direct exploratory technology, the task is reduced to the formalization of complex criteria of petroleum mineral resources, including the comparison and the description of oil and gas potential laws of studied territory by quantitative parameters of these criteria. Identification of their correlation dependencies and the search for new deposits using mathematical statistical methods are also of great importance. So if the solutions are so simple, a reasonable question appears: why do not they become the property of the geological community and are not used in the practice of prospecting works? The answer is simple and tough at the same time. Right decisions in this field are impossible without the "liberation" of Oil and Gas Geology from the old dogmas of denial this or that (biogenic, abiogenic) hypothesis of the origin of hydrocarbon deposits, in accordance with common sense. Geological conditions of occurrence of hydrocarbons in the earth's crust and the laws of physics, the interpretation of the data array of reflected signals on the base of geological and structural research results must be taken into account.

At one of the meetings, V.B. Porfiriev - an outstanding Ukrainian geologist said: "We, geologists, can make predictions of prospects generally, only on the scale of entire regions. We still cannot guide exploration and prospecting in specific regions and that is based on theoretical ideas about the conditions of oil formation and principles of its migration. Attempts of certain comrades to assert that the industrial oil-bearing capacity of a region has been opened on the basis of indications of a particular theory of the origin are either naive or dishonest.

No, we do not doubt in the principles on which our high-temperature abiogenic geochemical oil scheme is built, it consists of homogeneous and high watering accumulations organic substance. It is perfectly clear that if somewhere and someday the required conditions of this scheme are created, nothing else than oil forms".

Therefore, the facts were not opposed (Porfiriev, Brod, 1959).

Many years of experience showed that the efforts of the enthusiasts are not able to solve the problem in its system-applied aspect. Thus, despite the large number of disparate theoretical and experimental teaching materials, efficient technology of direct oil and gas exploration, particularly in non-traditional fields of crystalline rocks, was absent. This is connected with the fact that mainly chemists and microbiologists, geochemists and geophysicists were involved in the solution of this problem. Their main efforts were focused on solving the problem of direct exploration and that was based on a particular hydrocarbons origin paradigm, including the development of various methods of geochemical and geophysical studies of the principles of interpretation in the design of various types of devices and systems, 
concentrating in certain areas of geochemistry, seismic, electrical, geothermics, etc. Thus each of these researchers was a staunch "patriot" that concerns not only his method, but the basis of $\mathrm{HC}$ modification and the concepts that deal with its origin. Irreconcilable contradictions often appeared between representatives of the biogenic hypothesis and abiogenic, geochemists and geophysicists, even within a single direction (gas and microbiological survey, seismic, geothermics, etc.) (Lukin, 2004).

As it was mentioned earlier, during our investigations for creating direct exploratory technology, we relied on the fundamentals of the two paradigms of $\mathrm{HC}$ origin that is based on an integrated manner that own a wide range of search criteria.

As our STAGR experience showed that way of increasing the efficiency of oil and gas exploration is associated with the proposed new technology that is based on a systematic approach that is the interpretation of its results. Therefore, the comprehensive STAGR methodology is based on authors' scientific and methodological achievements in the field of direct and indirect exploratory methods, as well as improvements and implementation into practice of geological exploration of hydrocarbon deposits of the express research methods complex (structural-tectonic, geochemical, thermometric, atmogeochemical, aerospace, formational, seismometric) (Fig. 1) (Bagriy, Kizlat, 2004; 2009).

The positive results of using the proposed technology, that were derived at a number of Ukrainian facilities, including the crystalline rocks, were achieved on the basis of the implementation of fundamental researches that were written by I.M. Gubkin, V.A. Sokolov, P.N. Kropotkin, V.B. Porfiriev, A.E. Lukin. Created technology of direct search was tested and adapted to the industrial development of both conventional and unconventional oil and gas facilities, including impact structures or impact structures.

Moreover, during the near-surface thermometer and atmogeochemical studies, special equipment complexes were developed and introduced by us (Utility model patent, 2004; Utility model patent, 2009). They have necessary sensitivity and rapidity.

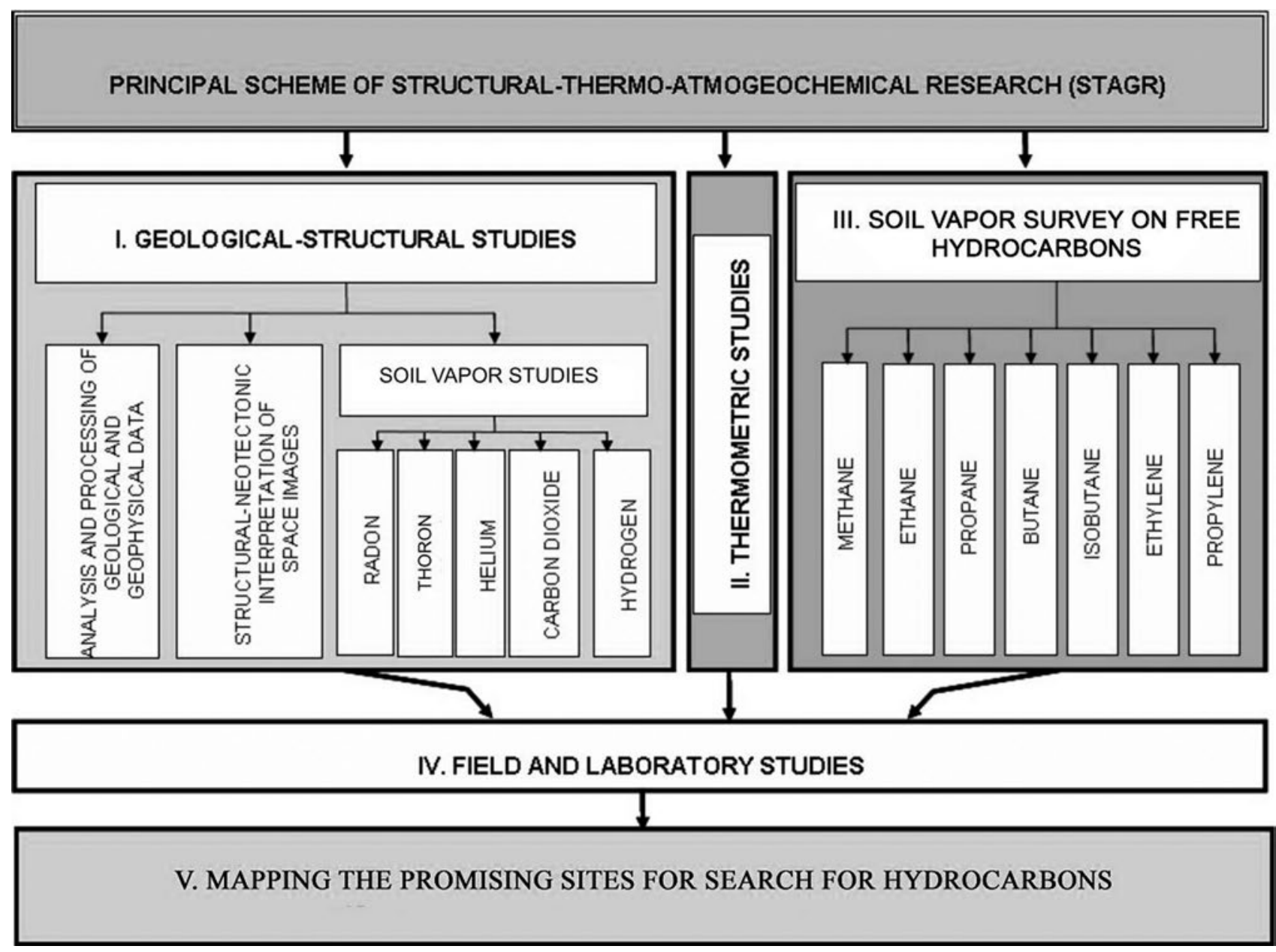

Fig. 1. Schematic diagram of geological-structural-thermal-atmogeochemical research (STAGR). 
Unlike most previously conducted studies of impact craters oil and gas potential in Ukraine, that are performed mainly in the profile form, or with the definition of certain indicators with different values, genesis and informativeness, STAGR study carried out in an area form, with sufficient amount of details of reasonable search and forecasting facilities on a clearly defined network of studies that were accurately geo-referenced. Thermometric, emanation and geochemical complexes of studies were performed in the same observation point. These features of the STAGR methodic provided the necessary complex, complete informativeness of data and results of the researches, and in addition grounded forecasted zoning works and, accordingly, the allocation of different prospects of local areas in search of hydrocarbons, refining the contours of productive structures for staging prospecting.

The developed STAGR technology allows determining position more reasonably with the pre- dictive significance of blocks and structures that are favorable for formation hydrocarbon traps and timed those oil and gas deposits. The results of the study are shown in the example of studying of OboIon' impact structure (Fig. 2-3).

The first stage is collecting, classification and interpretation of materials for constructing a geological model of the site. It includes the following: a detailed stratification, structural and tectonic structure peculiarities with oil and gas polygon or separate areas of researches, creation of computer factographic and cartographical with no databases, decoding of satellite imagery, geodynamics clarification, local and regional stratigraphic schemes, construction of appropriate maps that include structural fault-block tectonics, multiscale seismic (Fig. 2-3).

These materials form geological and structural basis for determining the future direction of researches, network of thermo-atmogeochemical testing and volumes of work.

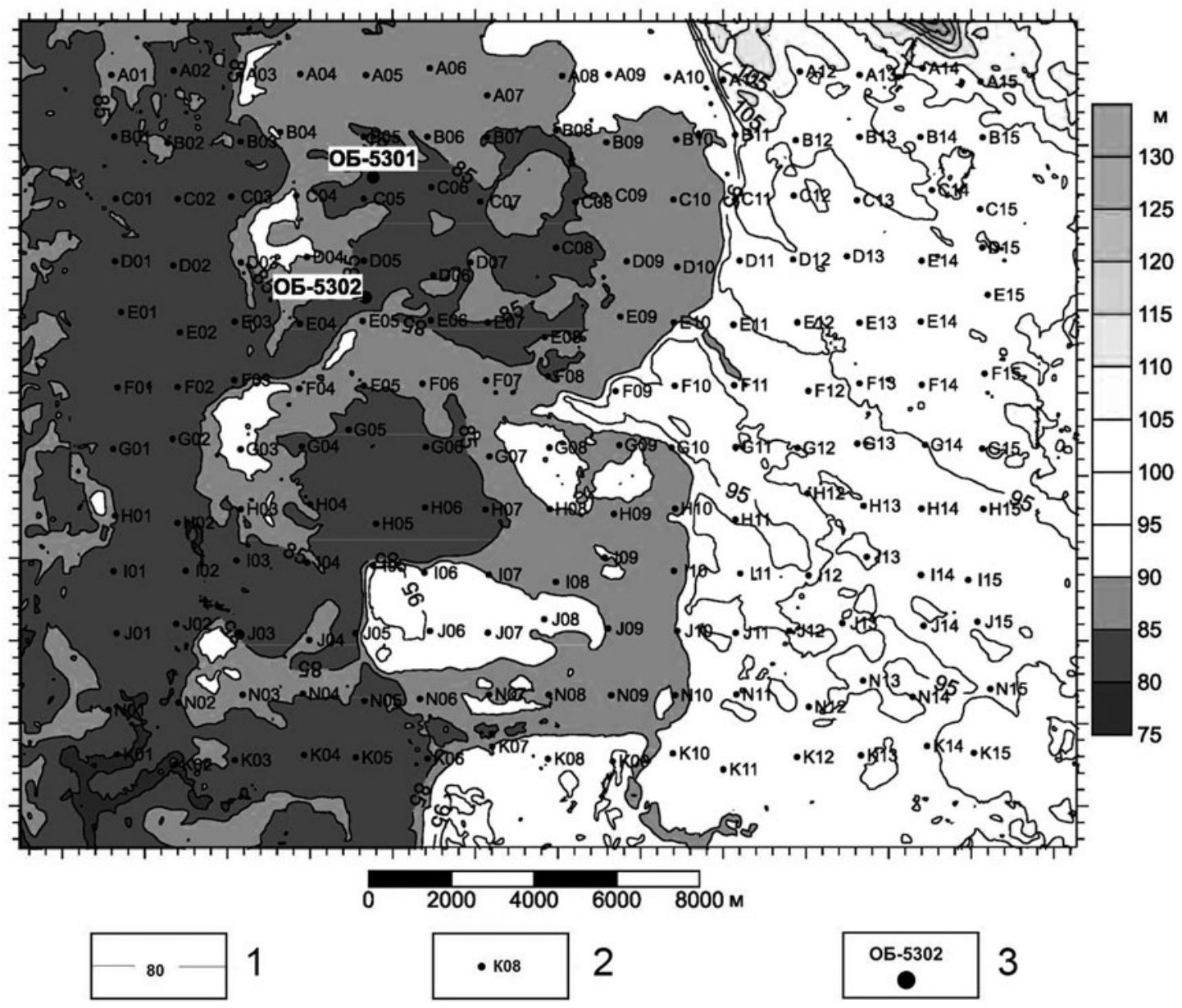

Fig. 2. Scheme of points of STAGR within Obolon' impact structure.

*1 - contour lines; 2 - observation points; 3 - boreholes.

* To figures 4,6,7,8. 


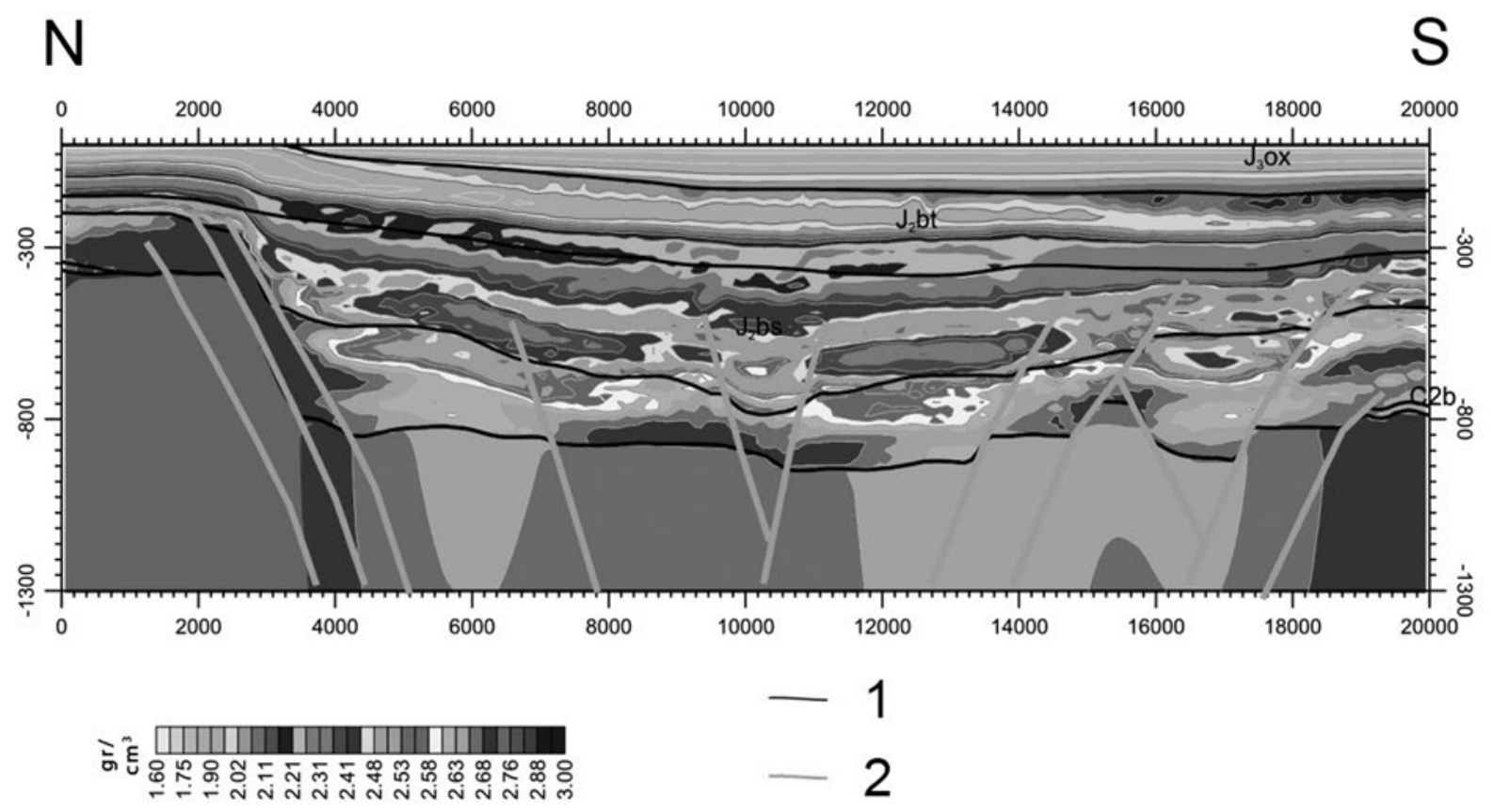

Fig. 3. Density structure along the cross line 285 to a depth of $1300 \mathrm{~m}$.

1 - seismostratigraphic horizons; 2 - lines of tectonic disturbances.

The second stage is polygon expeditionary or profile researches is emanation survey (determination of the activity of radon and thoron) (Fig. 4). Fault zones are defined with different permeability or near-fault territory.

To determine the content of helium, hydrogen, carbon dioxide in subsoil layer, which reflects migration zones, including fracturing zones and zones of tension and accumulation as the migration routes and areas with their hydrocarbon accumulations, sampling was performed (Fig. 4).

Many researchers point out that in different oil and gas bearing provinces of the world the link between local geothermal anomalies, and oil and gas deposits in the sedimentary cover was identified.

According to the laws of thermodynamics, local geothermal anomalies have a direction of thermal energy in accordance with the generalizing tendency to equalize the potential energy system. They evolve spontaneously in the vertical direction of the energy balance, during that heat may go from hot to cold, and not vice versa. In this case it is the surface direction of the reservoir where the thermal anomalies are formed and that indicates the hydrocarbon reservoir (Fig. 5).

The third stage is laboratory analytical studies of gas samples (determination of carbon dioxide, helium, hydrogen, methane, ethane, propane, butane, isobutane, pentane, isopentane, hexane, ethylene and propylene volumes) (Fig. 6-7).
The fourth stage is mathematical-statistical processing and data analysis (taking into account the information that was collected and systematized in the first stage), construction of computer cartographic models (both specialized in individual indicators and generalized predictive one) with usage of GIS technologies.

The fifth stage is comprehensive interpretation of received geochemical, geothermal and geological data. Atmogeochemical anomalies and confinement of elevated concentrations of hydrocarbon gases, oil and gas prospect with investigated objects are projected; corresponding recommendations are prepared for future researches (Fig. 8).

At the final stage, that deals with mapping of oil and gas areas, to increase the accuracy of forwardlooking decisions, it is very important to use integrated approaches; it is when oil and gas facility is considered as the result of a complex interaction of various factors and changes in education, it is also considered like a multidimensional model. It is explored by all possible methods, namely theoretically and practically.

Large amounts of data have received results that must be correctly interpreted and the degree of their information load should be estimated as well. It is possible only with the assistance of mathematical-statistical methods of calculation. Union of these methods in the system greatly simplifies 


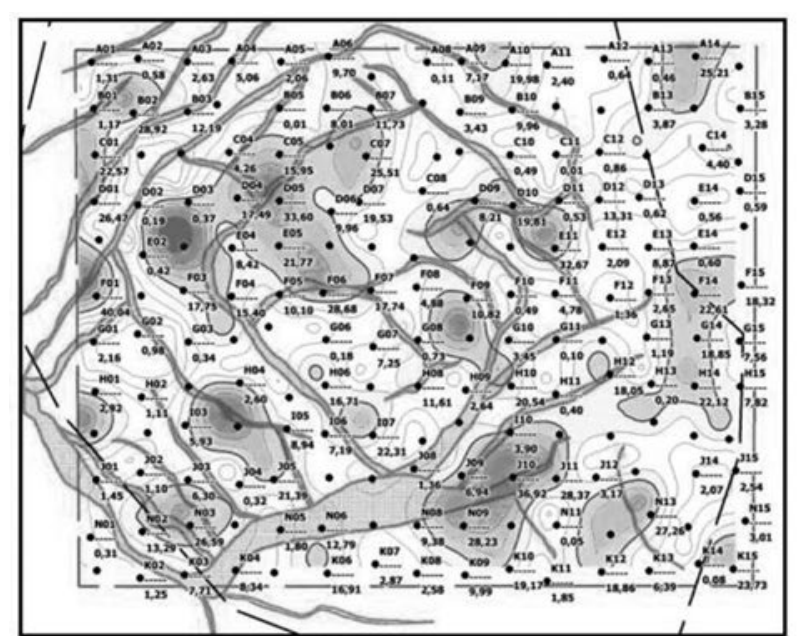

Radon

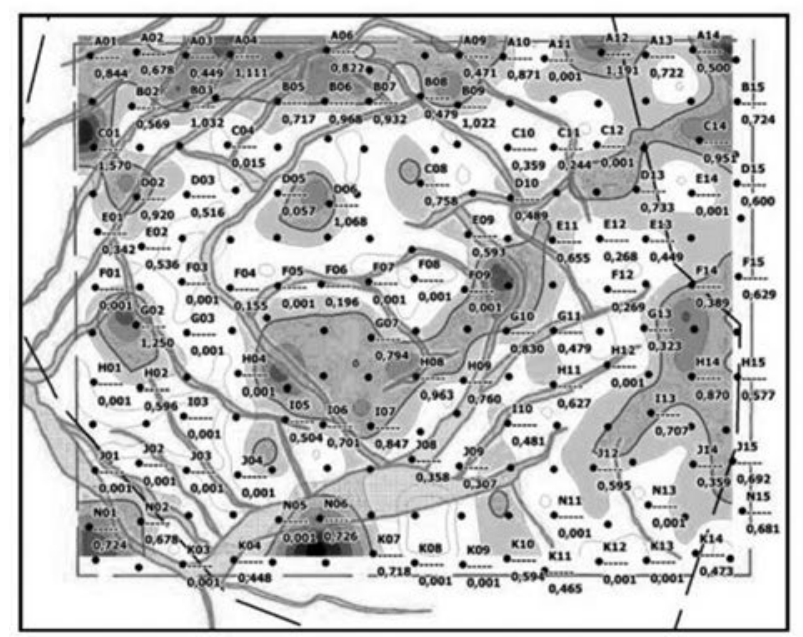

Helium

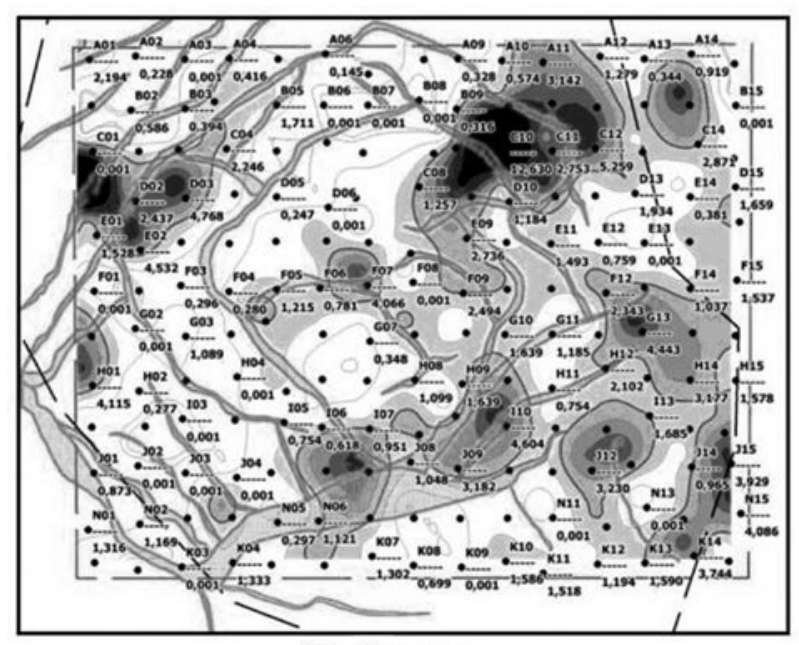

Hydrogen

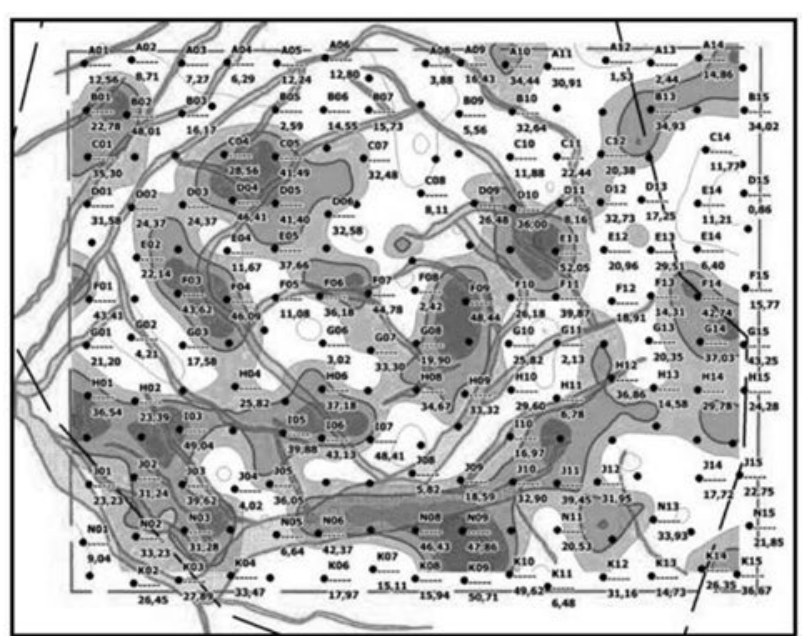

Thoron

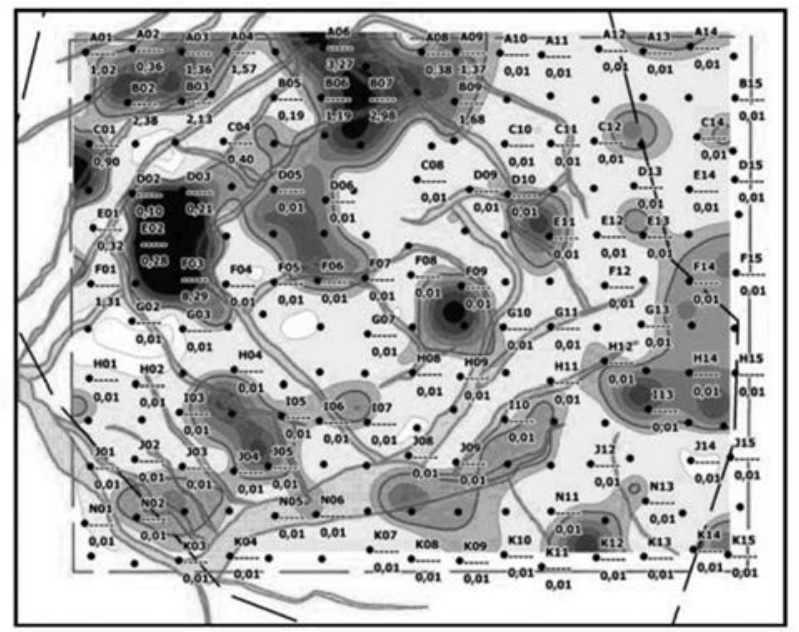

Carbon dioxide

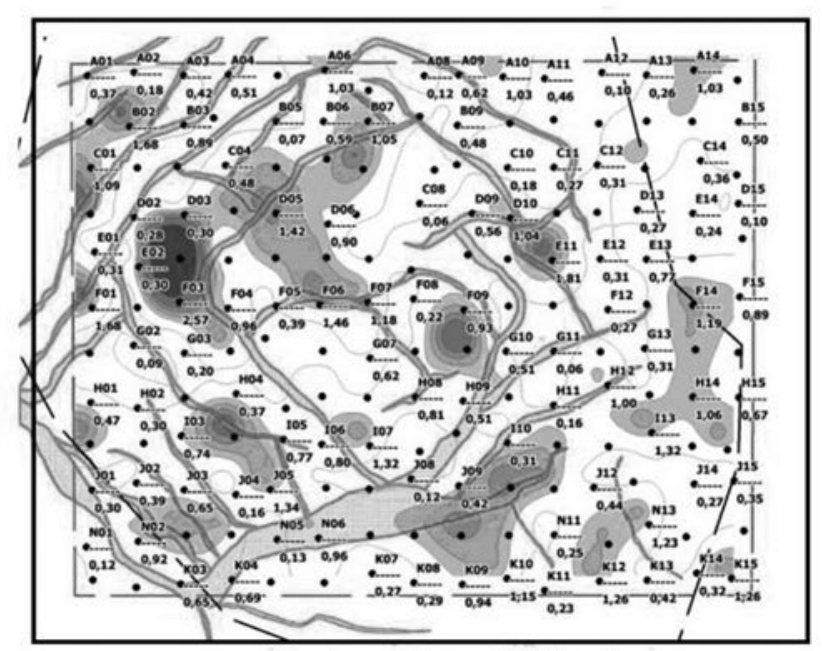

Integral coefficient

Fig. 4. The distribution schemes of radon, thoron, helium, carbon dioxide, hydrogen content in the subsoil air and integral coefficient at the territory of Obolon' impact structure (based on the structure map of the crystalline basement according to the 3D results). 


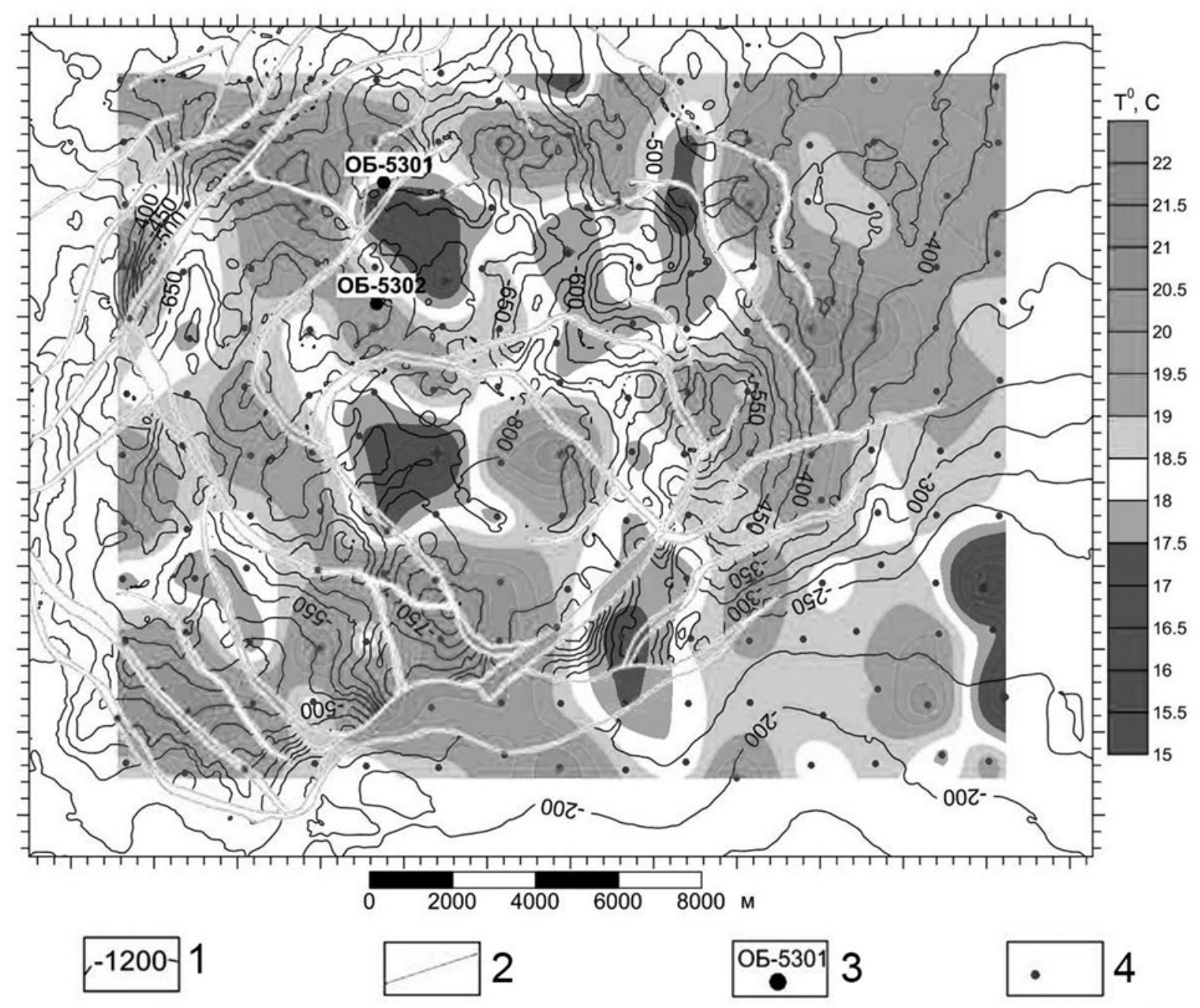

Fig. 5. The distribution scheme of temperature indicators $\left(T,{ }^{\circ} \mathrm{C}\right)$ of subsoil layer of Obolon' structure (based on the structural map of the crystalline basement according to the $3 \mathrm{D}$ results).

1 - isohypses of horizon $\left(\mathrm{J}_{3} \mathrm{bt}\right) ; 2$ - tectonic disturbances; 3 - boreholes; 4 - observation points.

the process of analyzing the data and makes it logically and mathematically correct, it significantly improves the search method. At the same time, the system of mathematical and statistical methods should accurately describe the actual geological conditions, without introducing unnecessary generalizations, or vice versa, it should not exclude the required data.

While searching $\mathrm{HC}$ fields, technological and analytical innovations must be combined with the growing technological capabilities at their extraction. In this case, search, exploration and development of $\mathrm{HC}$ fields will come to a new level.

The relevance of the study is caused by the need to improve the accuracy of predictive decisions that would rely on a system of mathematical and statistical calculations at realization STAGR technology.

\section{RESULTS AND CONCLUSIONS}

We have developed and tested a methodology of mathematical and statistical analysis of the STAGR results and set an optimal scheme for its implementation. The use of the methodology allowed us to refine the predicted contours within the studied areas, both on land and in sea areas.

In most cases, the results obtained with STAGR method are similar in the known natal places and they have minimum values on the vault and maximum on the wings. This mapping of deposits corresponds to the contour of impermeable traps. Minimum gas hydrocarbon geochemical indicators of the content $\mathrm{HC}$ almost always coincide with the minimum values of radon and thoron indicators that characterize permeable ones, and at or below background values indicate impervious area (zone trap formation). 


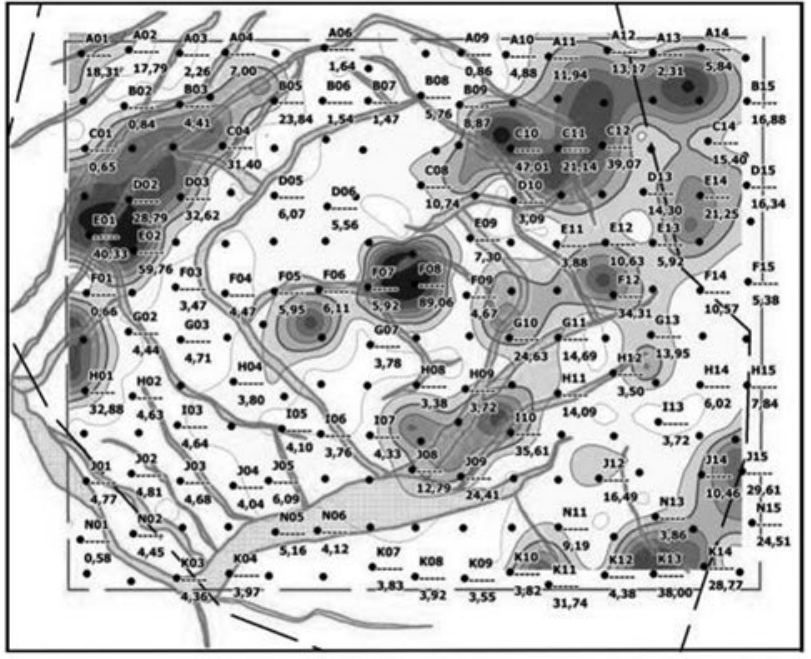

Methane

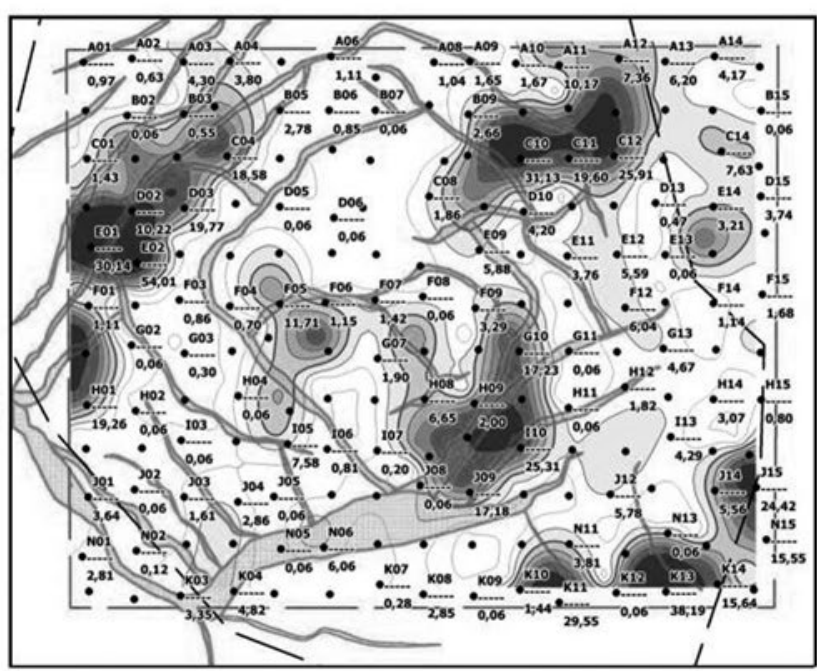

\section{Ethylene}

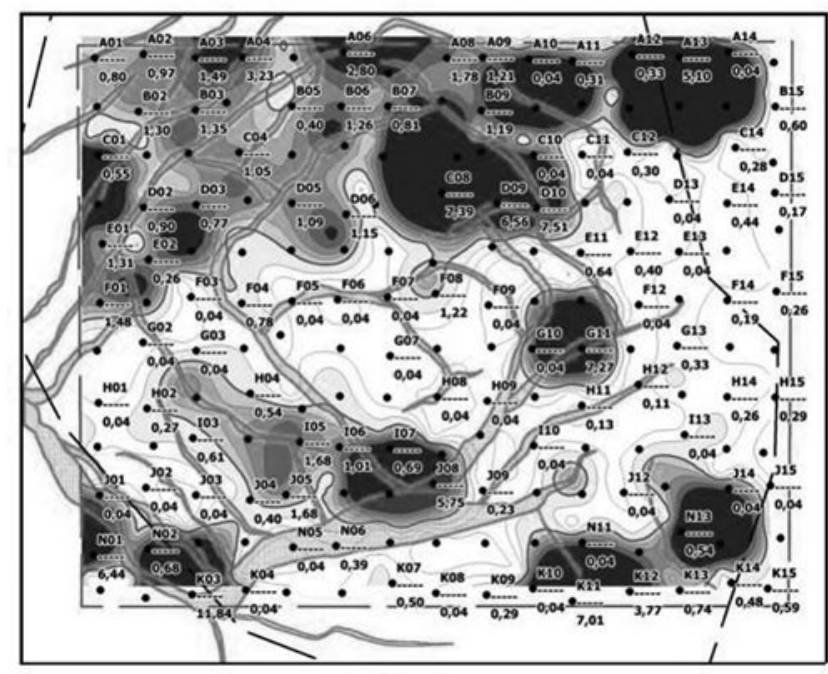

Isobutane

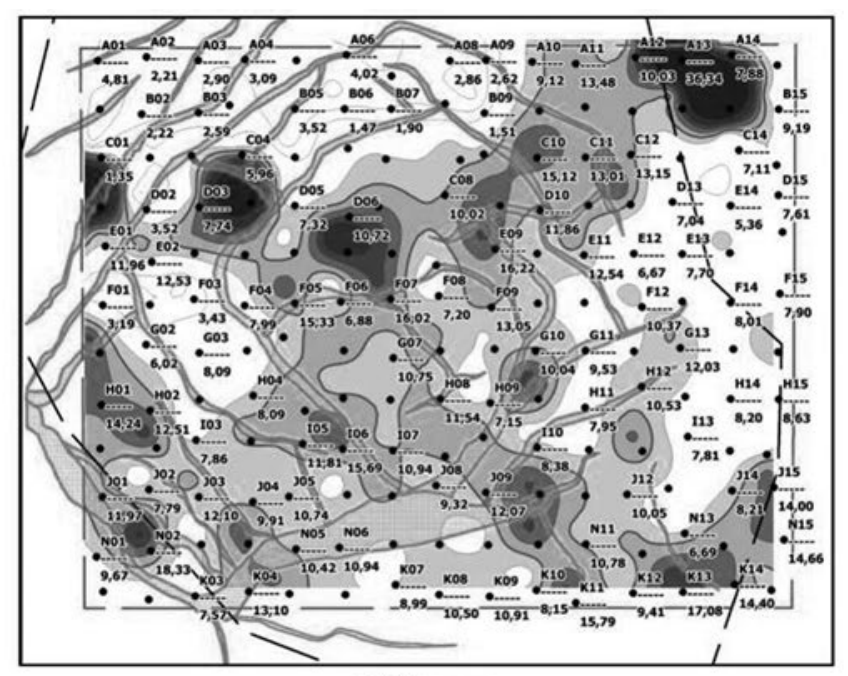

Ethane

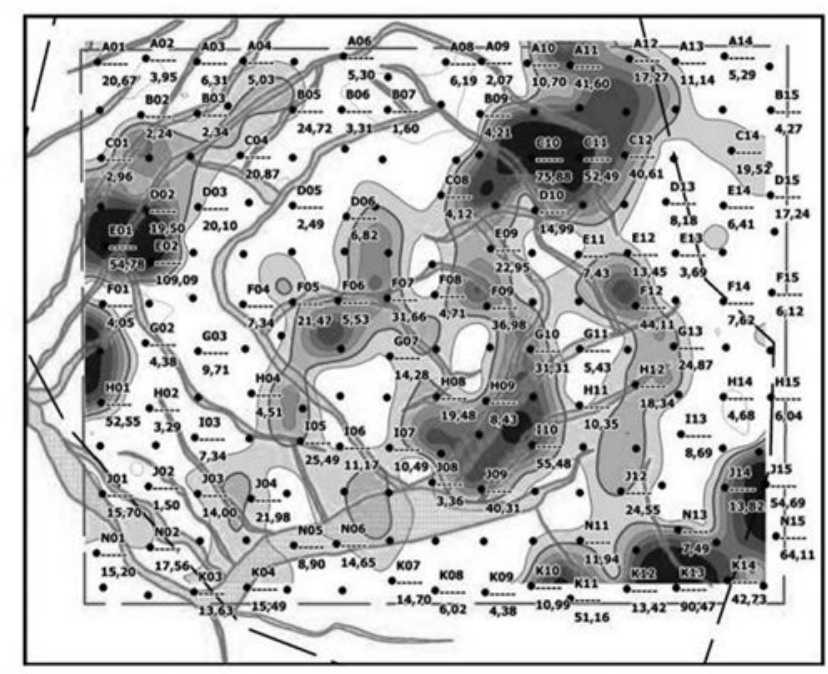

Propane

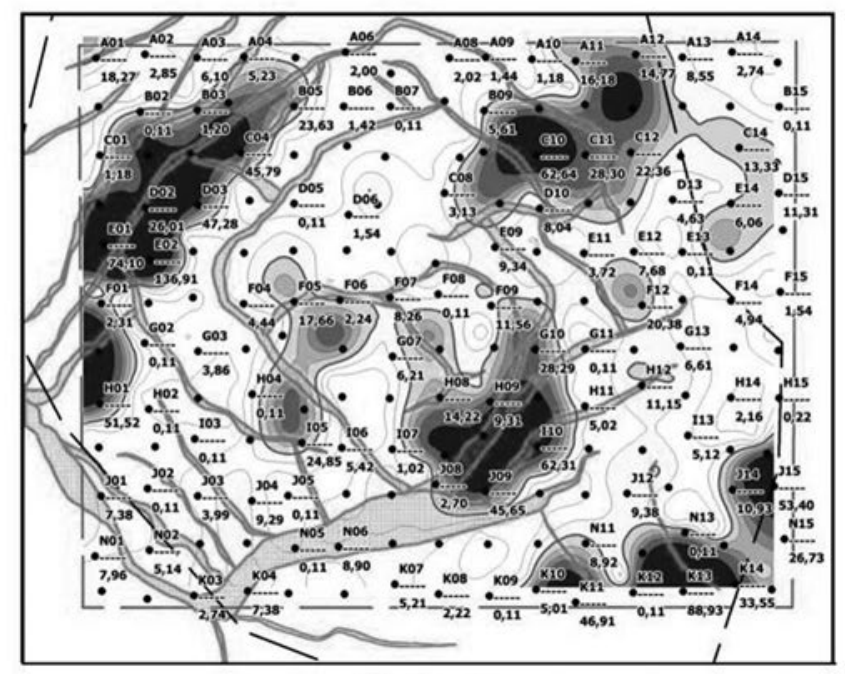

Butane

Fig. 6. Schemes of hydrocarbon content indicators and the amount in the subsoil air of Obolon' structure. 


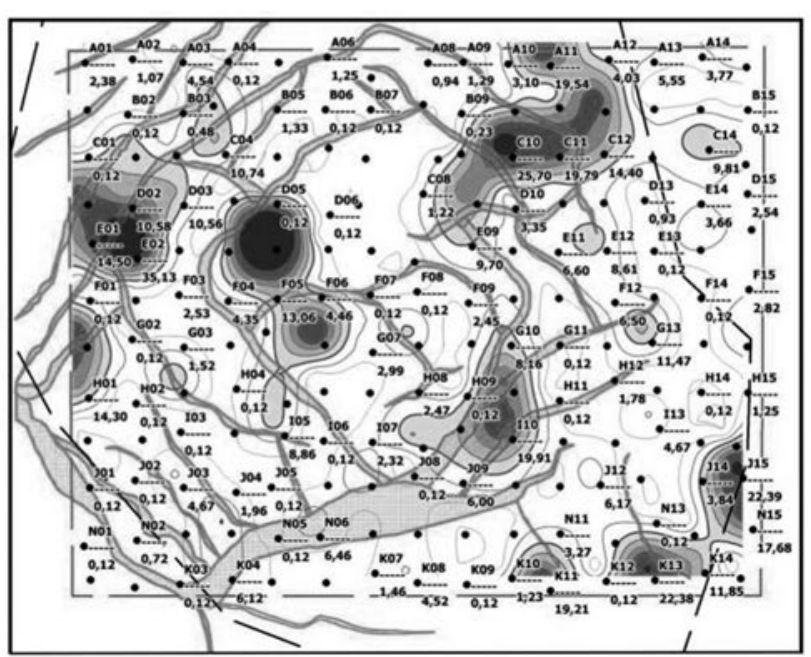

Propylene

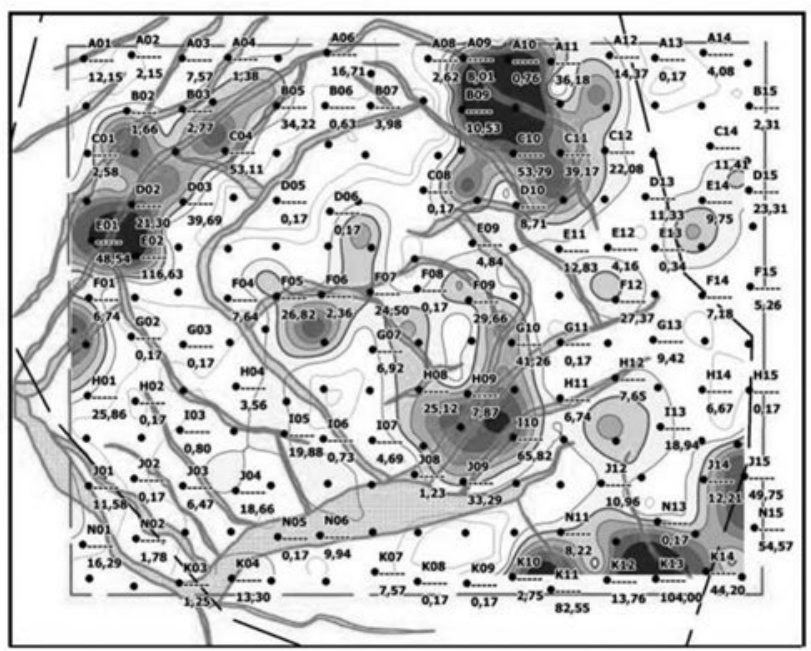

Pentane

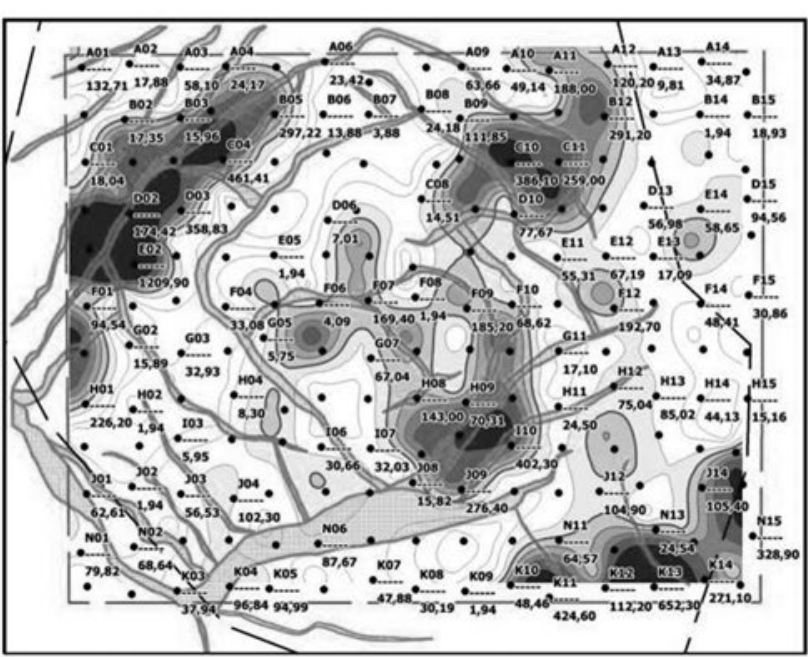

Isopentane

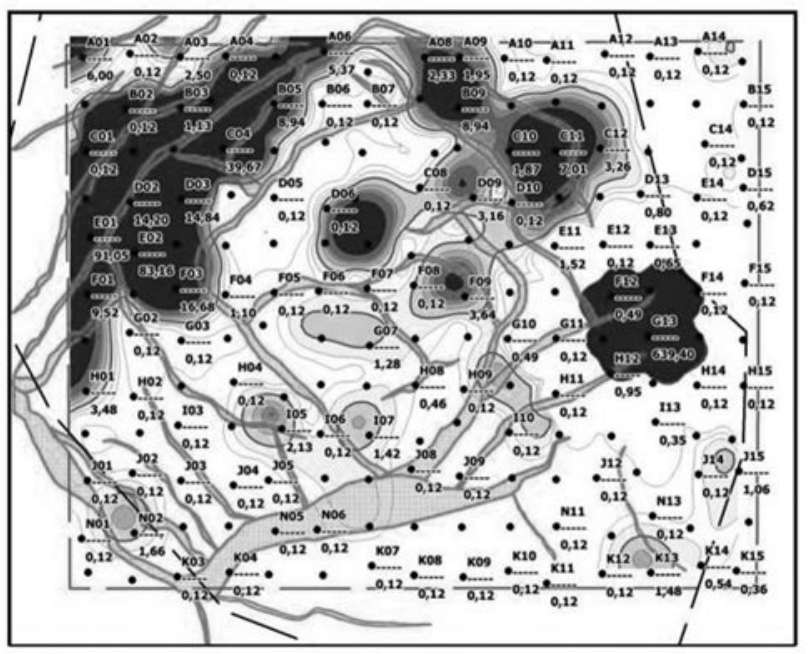

Hexane

Fig. 7. Schemes of hydrocarbon content indicators and the amount in the subsoil air of Obolon' structure.

Geometrization and prediction of fractured zones, zones of extension and their spatial location is a complex problem and its' solution is impossible without an understanding of joint deformation and fluid dynamic formation mechanism collectors fracture zones (stretching zones). The solution of this problem allowed to realize the tasks of mapping that deals with promising zones of collectors sedimentary cover development and crystalline basement (and associated with oil and gas). According to the proposed STAS technology, the practical significance of using complex of methods is invaluable on a unified genetic basis because, with rare exceptions, drilling in the described strata - is a direct risk of losing reservoirs on exploration stage of work due to uncertainty precise geometry. The impossibility of entire testing of homogeneous carbonate strata or granitic rocks, under ambiguous interpretation of GIS, in practice leads to omission of widespread productive areas. And this is only a part of the problems that oilmen have to face in low-permeability strata with fractured reservoirs.

Acceptance of two paradigms of oil origin, including a significantly positive experience of applying STAGR at studying more than 80 structures, led the authors to the systemic organization of complex data processing. The study of impact structures has a great importance during the development of the subsurface sedimentary strata and upper layers of the crystalline basement with a predominance of secondary fractures and porous-tricky-fractured reservoirs, tanks and related hydrocarbon deposits.

At present, two types of impact craters were identified - simple and complex. A bowl-shaped depression with capsized and upturned annular edge of shaft that is elevated above it is characterized for the first type. The complex craters have a central rising; if the diameter of the crater is more than 


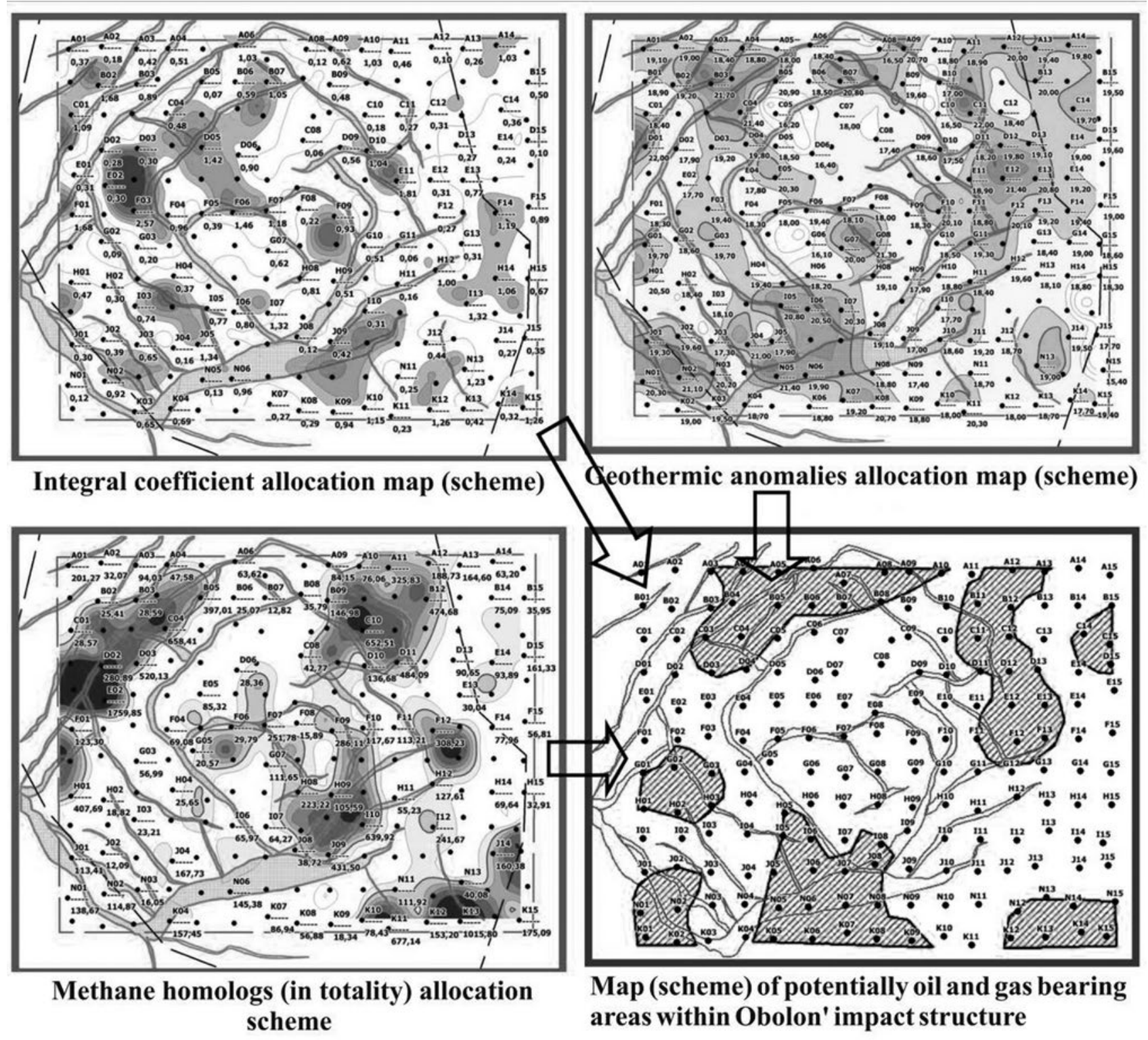

Fig. 8. Mapping (schemes) with the highlighting of potentially hydrocarbons bearing sites.

$30 \mathrm{~km}$, it can be replaced or accompanied by several concentric shafts and trenches, giving a multiring shape for an impact structure.

Taking into consideration all mentioned effects, it is important to know that a hit can instantly transform uncollected breed in porous and permeable. It can also change the structural conditions in occurrence of rocks of the target regardless the regional geology. When a big magnitude hits, all these changes have a very significant distribution.

The internal constitution of impact structures is characterized by the presence of the following structural and lithological complexes. They are: base, koptogenic, filling, overlapping and injection. The last builds up deep igneous rocks that are intruded in the ground and koptogenic rocks com- plexes, that are represented by sedimentary, igneous and metamorphic crystalline rocks of the target (point of impact), and where a crater is, and allogeneic breccia and impactites that fill the crater after the explosion, and a crater wall forming with explosive emissions coverings. A filling complex consists of sediments of lacustrine or marine genesis, it is deposited on the koptogenic complex, while the overlying complex - is the thickness of sedimentary rocks, that overlies simultaneously the base, filling and koptogenic complexes.

During assessment of hydrocarbon potential of impact structures, the possibility of applying STAGR search technology should be considered in the light of the oil and gas potential of sedimentary cover and crystalline basement (based on the analysis of the 
geological structure and oil-and-gas-bearing capacity of well-known impact structures - Avak, Ames etc.).

All these oil and gas showings are observed in the thickness of base and koptogenic complexes both in vertical and horizontal meanings, namely, the longer the distance to the target from the center of the impact (explosion), the weaker the shock metamorphism, but in the rocks of the filling complex it depends on the availability and location of erosion simulation products or rewashing koptogenic and base systems.

Most researchers come to conclusion that the cracks that are the main ways of hydrocarbon migration that occurs both in horizontal and vertical directions. Fissures in crystalline rocks and sedimentary deposits make the formation of natural reservoirs of oil and gas in the dense nonporous basement rocks possible, including rocks that are characterized by an increased sorption capacity. In recent years, a large amount of factual material is accumulated, and it can be assumed that it is due to the formation of intense fracturing in rocks of different origins, forms additional space and significantly increase the filtration properties of strata. In such a way occurs connection between petroleumgenerating and reservoir layers, and these processes contribute to the formation of deposits in "uncharacteristic" conditions.

In sedimentary and crystalline rocks, crack formation occurs under conditions of hydrostatic compression and stretching mass stress state.

According to Belousov's genetic classification of ruptured violations, untectonic ruptures relate to instantaneous process (explosions, strikes, meteor - impact structure) and include tensile, compression, shear, crack, rupture displacement, separation and chipping.

Different directions and ambiguity of the influence of these processes leads to a wide variety of cracks that have different genesis and dimensions, as well as changes in their deposition, and that of course, requires the classification of rupture dislocations and special techniques of mapping.

The offered STAGR processing methods enable to map faults and fracturing of rocks with different permeability, although there are many examples of the presence of high density of cracks in the nearfault zones and unquestionable role of the latter in the process of migration and the formation of hydrocarbon accumulations. The presence of hydrodynamically isolated deposits of oil and gas within one fold that is complicated by violation proves impermeability of faults. Frequently, acting as insulat- ing screens, they cause the formation of tectonically screened deposits. Consequently, we can speak about a double multidirectional influence of rupture dislocations in the formation of fractured reservoirs. On the one hand, there are areas of increased fractures that contribute to improving the filtration properties of rocks, and on the other - approaching ruptures the process of secondary mineral formation becomes much more intensive, making the cracks heal and impervious areas and confined him to an accumulation (traps).

One of important areas of our research in the mapping of fault zones of enhanced permeability (FZEP) was studying and mapping of intensity of the development of cracks and their permeability and the geography of location in rocks under different structural and tectonic conditions.

Conducted researches show that the structure of fault zones affects the distribution of break-out fractures (rising corresponds to centre of contact zone, depression corresponds to ring sag). The radial cracks form on a circular rising, longitudinal cracks oriented across the long axis of rising form on the arc part of oval rising and jointed by transversal cracks. The remote part of spherical vault or crater is complicated by a number of radial cracks. Concentric cracks often form under conditions of rising and tension of layers. Break-out cracks do not intersect themselves; they only joint and linklikely prolong each other.

Analysis of the results of structural construction of the reflected signals based on the data of aerospace researches and emanation survey make it possible to conclude that there is a various character of disposition and development of cracks. The peculiarity of strain field by transversal bending promotes the greater development of cracks at the convex surfaces of the layers. In the process of formation of the patterns in the vault generate zones of tension, occurs decompression of rocks, originate conditions of decontamination accompanied by radon anomalies.

An inverse relationship indicates for the longitudinal bending - the absence of fracture zones in the sags which contributes to the formation of zones of tension on the fold wings, and their surfaces became gentle approaching to the upper surface of models.

There are known seven impact structures of different ages and sizes in Ukraine, but for the present only one of them (Obolon') has been prepared for oil and gas drilling by the Institute of Geological 
Sciences of Ukraine in cooperation with "Naftogaz Ukraine". In addition, we studied three structures using STAGR (Table. 1).

Practical results of STAGR had shown sufficiently reliable properties in comparison with full-3D-survey.

On the basis of above material, all impact structures of Ukraine (Table. 1) are conceptually new geological targets in its gas and oil potential. It is advisable to drill an exploratory well on Obolon' impact structure for the following causes from this point of view. This impact crater has a diameter of 15$18 \mathrm{~km}$ on geo-structural data and more than $30 \mathrm{~km}$ according to the aerospace and geochemical studies. It is located on the watershed of the rivers Sula and Khorol in the Poltava region. Obolon' structure is situated closer than all other Ukrainian impact structures from oil and gas provinces of Ukraine which have a powerful industrial base and a large long-term experience of successful drilling and development of numerous wells. In addition, Obolon' structure is situated in a part of the southern edge of the Dnieper-Donets depression (DDD) which was sufficiently studied by geophysics and drilling.

Location of the crater in the border region with oil- and gas-bearing area and the presence of a thick layer of platform sediments here provide an opportunity to consider it as a probable oil- and gasbearing structure. A comparative research of the Obolon' structure and several petroleum craters in North America as well as data STAGR show closeness of their structure and indicate the probability of detection of hydrocarbon deposits in it.

The authors were interested in study of oil and gas capacity of impact structures in terms of both mapping features of sedimentary cover and crystalline basement, the location of the fault-block tectonic structures, fracture zones, zones of tension and eventually concerning with geochemical, geodynamic and thermodynamic characteristics and affinity to it predicted oil and gas-bearing areas.

The main objects of searches in impact structures, as described above, are over- and under-crater paleozones of fissure that occurred during the meteorite impact, forming a complex and intricate network of migratory canals and storage reservoirs for hydrocarbons.

In order to receive additional information about the assessment of the prospects of Obolon' structure and to refine the network of neotectonic active faults and fluid dynamic characteristics in 20112013 there were performed by us two time complex subsurface studies and mapping FZEP (Bagriy et al., 2002). Forecasting oil and gas potential, places with

Table 1. Impact structures of Ukraine

\begin{tabular}{|c|c|c|c|c|c|c|}
\hline \multirow[t]{2}{*}{ № } & \multirow{2}{*}{ Impact crater } & \multirow{2}{*}{ Location } & \multicolumn{2}{|c|}{ Coordinates, degrees } & \multirow{2}{*}{ Diameter, km } & \multirow{2}{*}{ Age, Ma } \\
\hline & & & north latitude & east longitude & & \\
\hline 1 & Boltyshskiy* & Kirovohrads'ka Oblast & 48,8 & 32,2 & $>50$ & $65 \pm 5$ \\
\hline 2 & Zeleniy Gai* & Kirovohrads'ka Oblast & 48,7 & 32,9 & 3 & $120 \pm 20$ \\
\hline 3 & Ilyinets & Vinnyts'ka Oblast & 49,1 & 29,2 & $3-7$ & 445 \\
\hline 4 & Obolon'* & Poltavs'ka Oblast & 49,5 & 32,9 & $>30$ & $160 \pm 30$ \\
\hline 5 & Rotmistrovka* & Cherkas'ka Oblast & 49,0 & 32,0 & 4 & $140 \pm 20$ \\
\hline 6 & Ternovka & Kirovohrads'ka Oblast & 48,1 & 33,6 & 3,5 & $260 \pm 10$ \\
\hline 7 & Western Belilovskiy & Vinnyts'ka Oblast & 49,44 & 29,0 & 4,0 & $115 \pm 10$ \\
\hline
\end{tabular}

* Were examined by STAGR 
revitalization of modern geodynamic processes and decompression (fracturing) of rocks which define the place of migration in the earth's surface compositionally different fluids, including direct indicators of hydrocarbon deposits have confirmed by studies.

On the basis of the results of these studies a comparative analysis of the correlation calculations were conducted by the authors. There were constructed the maps of the distribution of temperature, geochemical and hydrocarbon-gas anomalies. It allows delineate areas with the most favorable conditions for the localization of potential hydrocarbon deposits as much as possible, and on these grounds highlight promising areas to search for hydrocarbon deposits. The selected prospective areas tend to be local units within the outer forecasted main shaft in the spatial distribution. The promising areas in the central part of the DDD are highlighted with less confidence.

In order to study the features of the deep structure and predicting the spread of zones with development of various types of collectors in the territory of Obolon" area in conjunction with the "Naftogaz Ukraine" detailed precision complex of two-dimensional gravitational and magnetometric investigations was conducted and complex interpretation of geological and geophysical data was ultimately made. The main objectives of the study were:
Analysis, compilation and re-interpretation of existing geological and geophysical data concerning with the Obolon' area;

Implementation of the field high-precision gravimetric and magnetometric studies on a scale 1:10 000;

Conducting of field geochemical studies with application of modern methods of field and laboratory geochemical surveys on a scale 1: 200 000;

Identification of priority areas for further exploration for oil and gas, including the location of the primary holes.

While carrying out a comprehensive analysis of geological, geophysical and geochemical criteria which are typical for productive targets and thus characterizing the oil and gas areas, it was used criteria of petroleum capacity in Table 2.

On the basis of the results of conducted searches the prospective areas were mapped (Fig. 8).

In general, 14 impact structures within eight sedimentary basins in the world industry now are characterized by commercial petroleum capacity including following basins: Appalachian Basin, Beaufort Sea Basin, basins of Michigan and Powder River, Perm Basin, basins of Raton and Williston, in the depths of the United States of America, Alaska, Kentucky, Colorado, Michigan, New Mexico, Oklahoma, North Dakota, Texas and Wyoming, likewise

Table 2. The most promising petroleum-bearing areas determination criteria

\begin{tabular}{|c|c|c|c|}
\hline № & $\begin{array}{l}\text { Analyzable character- } \\
\text { istic }\end{array}$ & $\begin{array}{c}\text { Value of informative parameter corre- } \\
\text { sponding to positive sign of hydrocarbon } \\
\text { accumulation availability }\end{array}$ & $\begin{array}{l}\text { Geological, geophysical, geochemical prospecting indi- } \\
\text { cators }\end{array}$ \\
\hline 1 & Mass density & $\begin{array}{l}\text { Minimum } \\
\text { (for light hydrocarbons) }\end{array}$ & $\begin{array}{l}\text { Decrease in mass density on areas, improvement of reser- } \\
\text { voir properties and oil-and-gas saturation of stratum }\end{array}$ \\
\hline 2 & Temperature & Minimum & $\begin{array}{l}\text { Increase in temperature above hydrocarbon deposits and } \\
\text { tectonically stable zones }\end{array}$ \\
\hline 3 & $\begin{array}{l}\text { Sum of free hydrocar- } \\
\text { bons }\end{array}$ & Halo-effect & $\begin{array}{l}\text { Maxima coincide with tectonically active zones and oil-and- } \\
\text { gas pool collapse areas }\end{array}$ \\
\hline 4 & $\begin{array}{l}\text { Alkanes and alkenes cor- } \\
\text { relation coefficient }\end{array}$ & Lack of anomalies (or lowest value) & $\begin{array}{l}\text { Anomalous zones coincide with oil-and-gas pool collapse } \\
\text { areas }\end{array}$ \\
\hline 5 & $\begin{array}{l}\text { Radon and carbon diox- } \\
\text { ide contents integrated } \\
\text { coefficients }\end{array}$ & Lowest value & Maxima coincide with tectonically active zones \\
\hline 6 & Helium content & Availability of anomaly within oil-bearing area & Availability of circular helium anomaly round the deposit \\
\hline 7 & $\begin{array}{l}\text { Local gradient maxima of } \\
\text { geomagnetic field }\end{array}$ & $\begin{array}{l}\text { Availability of maxima of appropriate form } \\
\text { and intensity which are typical for basic and } \\
\text { ultrabasic intrusive bodies }\end{array}$ & $\begin{array}{l}\text { The ways of hydrocarbon migration confined to selvages of } \\
\text { intrusive bodies }\end{array}$ \\
\hline
\end{tabular}


in Canadian provinces such as Alberta, Ontario and Saskatchewan.

To this list of "land" impact structures apparently it should be added submarine impact structure Montagnais, so far as oil and gas drilling was carried out here.

However, neither oil nor gas are found as a result of the drilling and sampling of dissected section, so impact structure Montagnais is the first submarine impact crater in the world, which became the subject of oil and gas exploration and had been given a negative result. But perhaps the fact is that it is impossible to decide the fate of a radically new direction and a large geological object practically without sufficient scientific evidence on the results of drilling of only one well and without special technology research and special apparatus complexes.

In the state of Dakota, United States, immediately to the south of the Canadian border and about $24 \mathrm{~km}$ to the west of Sherwood, in 1977, it was determined commercial oil and gas capacity of impact crater Newporte (another name - De-Lac). This is the only one impact structure where commercial oil and gas were derived from the crystalline basement and its weathering crust and where there is no central uplift, and wells are located in the area of the deflection, in zones of subcrustal stretching, which confirms our search-fundamental scheme. This impact structure is in the form of a depression and is $3.2 \mathrm{~km}$ in a diameter, with its fringing concentric annular shaft which is folded by Precambrian schist, with Cambrian-Ordovician "sandstone" Deadwood.

Much prominence is given now by many scientists and productions to Siljan ring and to the world's first ultra-deep exploratory wells for oil and gas in granites within Paleozoic Siljan impact structure. According to the STAGR technology, we had attempted to analyze aerospace surveys for possible errors in the founding of these wells. The first well is located on the Baltic Shield in central Sweden, at $240 \mathrm{~km}$ to the north-west of Stockholm. Impact structure is $42-52 \mathrm{~km}$ in diameter; it consists of a central core and an annular trough which is partly filled by chain of lakes with the largest lake Siljan of $125 \mathrm{~m}$ in depth. The central uplift, or nucleus of Siljan impact structure, is eroded and composed of coarse-grained Precambrian granites; koptogenic complex is not only removed, but the upper part of the central uplift, which had previously diameter of $12-15 \mathrm{~km}$, has been cut by erosion. There are revealed the cones of destruction of $0.5 \mathrm{~m}$ in height within these granites.
Apparently, producing of heavy oil in the first half of the eighteenth century from the many wells on the Osmond hill at the Siljan lake in the Lower Paleozoic rocks filled annular groove-graben which located in a vast field of Archean crystalline igneous and metamorphic rocks contributed to development of scientific basis for the search of oil and gas in granites of under-crater fracture zone within Siljan impact structure. This small deposit in the Ordovician sediments was limited by faults and composed of bitumen and mineral wax. In several places on the Siljan lake shores tarry-type oil leak out of cracks in granites which make up partially naked base of Osmond mount. It had been found abnormally high concentrations of radon near these seepages of oil from granite, which serve as negative criterion of possible traps at the preliminary stage.

It had been revealed very weak shows of methane and hydrogen in seven shallow exploratory wells in Siljan Ring. Within one of them drilled through the sedimentary sequence of $133 \mathrm{~m}$ in depth, the methane was found in granite at a depth of $458 \mathrm{~m}$ and in much larger quantities than in any of the other less deep wells. The methane in this well is $275 \mathrm{~m}$ below the top of granite, and $275 \mathrm{~m}$ below than any hypothetically nearest gas source rock. Many researchers were regarding such shows as a very serious argument that natural gas containing radon, even now continues to migrate from the deep granite subsoil. Gravitational and seismic researches were conducted here which indicate the presence of "layers" with significant porosity in fractured, crushed granite and "layers" that can play the role of seal rocks in granites, within under-crater zone.

According to proposed technology, there are two criterions which are negative indicator in this case, in terms of the positive predictive characteristics which are necessary for exploratory wells laying. Compression zone and dedicated to him crustal cracks, reflected by radon anomalies, are not able to serve as traps and seals, as they are located in permeable cracks on the convex projections and compression zones of the central uplift (Fig. 9).

Exploratory well in the north-eastern part of the Siljan structure fell into specific "halo" produced by hydrocarbons. This "halo" indicates that the entire complex of hydrocarbons has extracted here along the contour of the degassing tube for a very long time and that somewhere beneath the Siljan crater should be oil or gas deposit. According to our scientific-methodological and theoretical develop- 


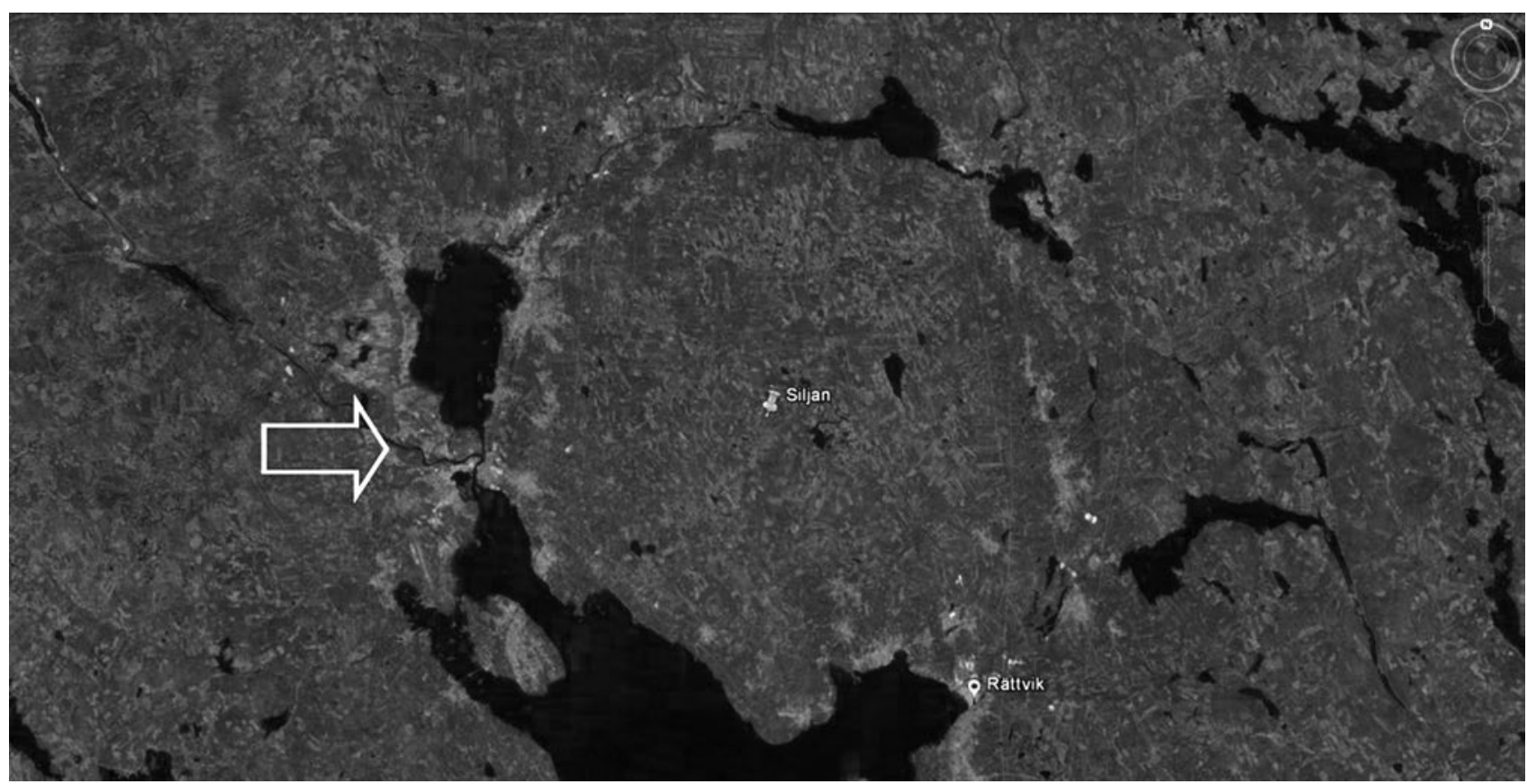

Fig. 9. Outline of Siljan structure on satellite image Landsat ETM+.

ments, as well as technology STAGR, the drilling in the north-eastern part of the structure within the "halo", practically in most cases leads to a negative result, since the higher value of the reflected hydrocarbon signals indicate degassing processes in contours of traps and can serve as a remarkable exploratory factor in area survey (Fig. 9).

As we can see, already at early stage of validation of predictive areas two significant mistakes have been made which subsequently led to the economically disastrous negative results in both material and financial, as well as in the moral and scientific terms.

Before to begin the drilling of Gravberg-1 well, company "Vattenfall" organized a group of five experts. The experts went to Siljan impact structure (impact structure), studied its geology and the seepages of oil and gas and submitted a report in which unanimously opposed to gas drilling here, confirming the impact structure nature of Siljan Ring. Experts pointed out that in six previously drilled shallow boreholes rock is not porous enough as for the collector rock of gas and is not impervious enough as for seal rock and that the interpretation of the elements of the deep structure which are identified by areal geophysical investigations as probably sealed reservoirs is speculative.

Negative or positive prediction without any substantiated scientific approaches looks quite unconvincing on the results of the shallow wells located only in areas of hydrocarbon seepage.
Based on our vast experience of mapping of fault zones of enhanced permeability, under the conditions of the anomalous values of koptogenic central complex with maximum values of $\mathrm{Rn}$-anomaly all registered hydrocarbon gas anomalies in the form of a ring "halo" in the drilling process have been little consolation for forecasted hydrocarbon accumulations because fractured permeable zones which are traced from the basement to the surface are confined to such areas.

Based on our extensive experience, as a small consolation, these areas of gas-emanation degassing are promising for water at the cracks with different flow rates. Such search operations have been carried out by us in terms of the Ukrainian Shield for water supply of small urban agglomerations, as well as the private water supply. Coefficient of success was almost 1.

When the well has passed $6.6 \mathrm{~km}$ in Precambrian crystalline rocks, hydrocarbons $\mathrm{C}_{1}-\mathrm{C}_{5}, \mathrm{H}_{2}, \mathrm{CO}_{2}$, $\mathrm{O}_{2}$, He, radon, and nitrogen have been identified and quantified by geochemical studies, which is a confirmation of the negative predictive results. Also the isotopic analysis of hydrocarbons, hydrogen and helium was conducted. All these results in the form of $\mathrm{He}, \mathrm{H}_{2}$ and $\mathrm{Rn}$ anomalies in complex also are more typical for permeable zones than for the accumulations of hydrocarbons.

On the basis of drilling results the views of many researchers divided: Siljan Ring is one of the worst places in the world to find abiogenic hydrocarbons 
according to one group, and, on the opposite, it is one of the best places according to another group. In our opinion, it is not reasonable to make such statements without sufficient justification on the whole range of proposed research.

According to data of commercial oil and gas capacity of impact craters in Canada and the United States, all major impact structure should not be seen only as a "pipe degassing" of the upper mantle of the Earth in general but also as a place of potential commercial oil and gas accumulation, the possible extent of which deserve to be studied by proposed technology not less than Siljan Ring. It is believed that the wealthy experience of oil and gas history of the northern part of Western Siberia and Tatar arch also contributed to the negative forecasts in ultra deep drilling.

We had carried out a detailed structural-neotectonic interpretation of satellite images in the process of a preliminary study for oil and gas within the Siljan structure (Sweden).
According to results of remote researches its complex structure was mapped. A large number of lineament zones argue in favor of large modern neotectonic activity throughout. Zones of lineaments often coincide with fragments of the regional tectonic disturbances (Lyalko, Popov, 2012).

To compile detailed decoding schemes, satellite images Landsat ETM+ have been used. First of all, it was 8th channel of high definition, increased to scale 1:50 000 (Fig. 9).

The main structural elements which are interpreted within the area are local lineaments and circular structures (Fig. 10).

It was carried out a statistical analysis of the field of lineaments using the software "WinLESSA" on the basis of created detailed decoding scheme. Based on the analysis there were built rose of lineaments of Siljan structure and the density map of lineaments.

According to rose of lineaments, the most common within Siljan structure are lineaments of north-north-

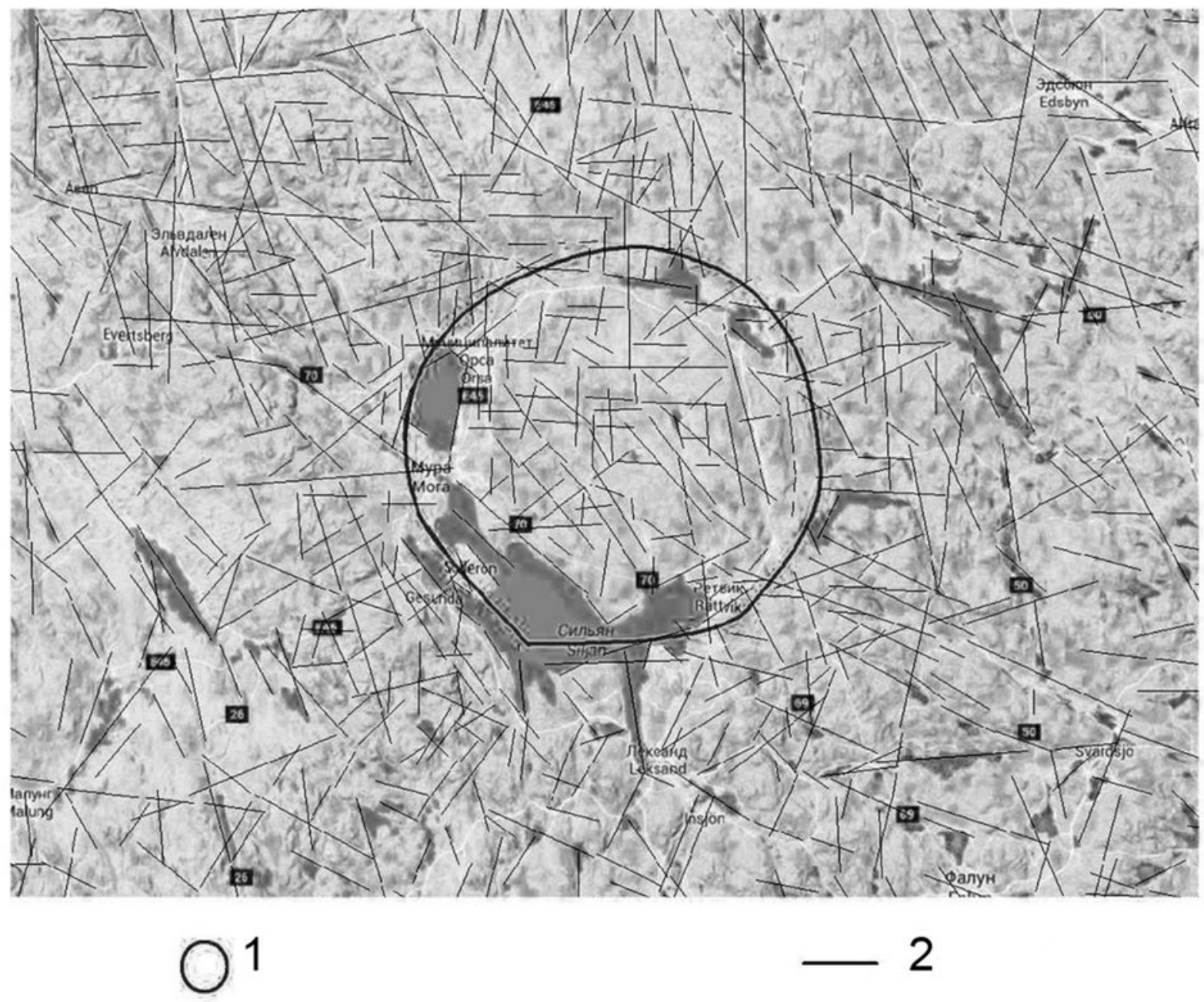

Fig. 10. Lineaments and circular elements of the arc structure are being imposed on modern landform and hydro-system: 1 - circular structure; 2 - liniaments. 
west $\left(330^{\circ}-340^{\circ}\right)$ and latitude $\left(270^{\circ}\right)$ trends, lineaments of meridional direction are less pronounced.

On the lineaments density map stands out clearly the entire structure characterized by highest (1250-1750 pixels $\left./ \mathrm{cm}^{2}\right)$ and high values of density of lineaments (1000-1700 pixels $\left./ \mathrm{cm}^{2}\right)$. At the same time, the peripheral part of the structure is characterized by a change from high to medium values of lineaments density. This distribution is a reflection phase of lineaments within the structure.

Geomorphological analysis of Siljan structure made on the map with 3D topography showed that the structure is expressed in the present relief as a rounded depression.

Within the Siljan structure at the preliminary stage of application STAGR technology can already distinguish the most promising areas coinciding with zones of deflections which corresponds to the middle and lower values of densities of lineaments, and hence, respectively, belonging to the impermeable areas (seals), which should be considered as promising areas for staging of detailed investigations.

Central uplift which related to areas of ultimate density of lineaments serves as zone of hydrocarbon degassing. Our conclusions confirm significant radon anomalies which reflect the fault zones of enhanced permeability and hydrocarbon gas anoma-

\section{REFERENCES}

Bagriy I.D., 2010. Utility model patent № 47419, IPC (2009) G01V 9/00, G01V 11/00. The method of mineral deposits forecasting. Applicant and owner Institute of Geological Sciences of NAS of Ukraine. u200913524; 25.12.2009; publ. 25.01.2010, Bul. № 2, 2010. (In Ukrainian).

Bagriy I.D., Gladun V.V., Dovzhok T.Ye., 2002. Experience of predicting of high permeability fault zones. Oil and gas industry (Naftova i gazova promyslovist), No 3, pp. 3-7. (In Ukrainian).

Bagriy I.D., Hozhyk P.F., 2009. Patent № 28176. 31.03.2009. A comprehensive methodology (structural-thermal-atmogeochemical research (STAGR), applicant and owner IGS NAS of Ukraine. (In Ukrainian).

Bagriy I.D., Kizlat A.M., 2004. Utility model patent № 2641, IPC 7 C02F1/20. B01D19/00. Portable samplerdegasser. Applicant and owner Bagriy I.D., Kizlat A.M., № 2003065643; 18.06.2003; publ.15.07.2004, Bul. № 7, 2004. (In Ukrainian).

5. Bagriy I.D., Kizlat A.M., 2009. Utility model patent № 43086, IPC (2009) B01D 19/00. Acoustic degasser. Applicant and owner Institute of Geological Sciences of NAS of Ukraine. u200905476; 29.05.2009; publ. 27.07.2009, Bul. № 14, 2009. (In Ukrainian). lies, and, of particular importance - the oil shows in the subsurface sediments, which also indicates the absence of fluid-permeable screens.

According to the rose of lineaments, unproductive wells drilled within the impact structure occur in the zone of significant density of lineaments and the well in the north-eastern part occurs in the gas halo effect which also indicates the absence of reliable seals and, therefore, no possible perspective areas for hydrocarbons.

According to rose of lineaments, the areas of depression characterized by lower density and are promising for stage of forecasting research.

Thus, it is necessary to conduct additional studies of the surface within Siljan structure. Their composition and stages of implementation may be defined in accordance with our scientific and methodological developments, proposed technology and search patterns based on the complex STAGR which were established and implemented on impact structures of Ukraine.

The authors' proposals and development of assessment of impact structures for oil and gas capacity using new technologies do not claim to uniqueness and final conclusions. It can be discussed in the course of discussions or work of researchers and productions which are interested in increasing of mineral resource base of hydrocarbons, including non-traditional sources.

Патент України № 47419 на кор. модель МПК (2009) G01V 9/00, G01V 11/00.Спосіб прогнозування родовищ корисних копалин. Багрій І.А.; заявник і власник Ін-т геол. наук НАН України. и200913524; 25.12.2009; опубл.25.01.2010, бюл. № 2, 2010 р.

Багрій І. А. АосвіА прогнозування розломних зон піАвищеної проникності / І. А. Багрій, В.В.ГАауун, Т. Є. Аовжок. // Нафтова і газова промисловість. - 2002. - №3. C. 3-7.

Свідоцтво України № 28176 авторського права на твір "Комплексна методика (структурно-термо-атмогеохімічних АосліАжень (СТАГА)". І.А. Багрій, П.Ф. Гожик; заявник і власник ІГН НАН України, реєстрація 31.03.2009.

Патент України № 2641 на кор. модель, МПК 7 CO2F1/20. B01D19/00. Портативний пробовіАбірник-Аегазатор. Багрій І.А., Кізлат А.М.; заявник і власник Багрій І.А., Кізлат А.М. № 2003065643; 18.06.2003; опуб^.15.07.2004, бюл. № 7, 2004 р.

Патент України № 43086 на кор. модель МПК (2009) B01D 19/00. Акустичний Аегазатор. Багрій І.А., Кізлат А.М.; заявник і власник Ін-т геол. наук НАН України. и200905476; 29.05.2009; опубл. 27.07.2009, бюл. № 14,2009 р. 
Gozhyk P.F., Bagriy I.D., Gladun V.V., Gurov E.P., 2010. Forecasting of oil and gas capacity of Obolon' impact structure by a complex of surface methods. Geological journal (Geologichnyi zhurnal), No 3 (332), pp. 7-16. (In Ukrainian).

Lukin A.E. 2004. Direct search for oil and gas: the causes of failures and ways to increase efficiency, Geologist of Ukraine (Geolog Ukrainy), No 3, pp. 18-43. (In Russian).

Lyalko V.I., Popov M.A. (eds)., 2012. Satellite methods for exploration of mineral resources. Kiev, Carbon-Ltd, 436 p. (In Russian).

Porfiriev V.B., Brod I.O. (eds.)., 1959. The problem of oil migration and formation of oil and gas accumulations. Moscow: Gostoptekhizdat, 423 p. (In Russian).

Timurziyev A.I., 1989. Justification of structural and geomorphological method to forecast local zones of the newest extension. Geology of USSR (Sovetskaya geologiya), No 1, pp. 69-79. (In Russian).
Гожик П.Ф. Прогнозування нафтогазоносності Оболонської імпактної структури комплексом приповерхневих методів / П.Ф. Гожик, І.А. Багрій, В.В. Гладун, Є.П. Гуров // Геологічний журнал. - 2010. - № 3 (332). - С. 7-16.

Аукин А. Е. Прямые поиски нефти и газа: причины неудач и пути повышения эффективности / А. Е. Аукин. // Геолог України. - 2004. - №3. - С. 18-43.

^ялько В. И. Спутниковые методы поиска полезных ископаемых / В. И. Аялько, М. А. Попов. - Киев: Карбон-АтА, 2012. - 436 c.

Порфирьев В. Б. Проблема миграции нефти и формирования нефтяных и газовых скоплений / В. Б. Порфирьев, И. О. Брод. - Москва: Гостоптехиздат, 1959. - 423 с.

Тимурзиев А. И. Обоснование структурно-геоморфологического метода прогноза ^окальных зон новейшего растяжения / А. И. Тимурзиев. // Советская геология. - 1989. №1. - С. 69-79. 